процесу підготовки загалом. Найбільш ефективними в контексті досліджуваної проблеми обрано такі комплекси рефлексивних вправ, як «Телефон довіри», «Плюс-Мінус», «Завершення речення», «Готель», «Аркуш, який гуляє колом», що пропонуються в сучасній науково-методичній літературі [4].

Підсумовуючи викладене вище, зазначимо, що впровадження контекстного навчання на заняттях із біонеорганічної хімії в медичному коледжі передбачає:

- наближення процесу навчання до майбутньої професійної діяльності медичних спеціалістів або ії фрагментів шляхом використання системи проблемних задач та вправ;

- застосування проблемних методів навчання, у яких моделюються реалії професійної діяльності;

- реалізацію інтерактивних методів навчання шляхом спілкування і взаємодії всіх учасників навчального процесу;

- застосування проектних технологій навчання, результатом яких $\epsilon$ висвітлення шляхів розв'язання навчальних задач у контексті майбутньої професійної діяльності;

- узагальнення власних навчальних досягнень й аналіз власних дій, зокрема пізнання самого себе, шляхом рефлексивних дій та вправ.

Ураховуючи визначені особливості, уважаємо, що реалізація положень контекстного навчання на заняттях із біонеорганічної хімії є ефективною і сприяє формуванню предметної компетентності на більш високому рівні.

\title{
Література
}

1.Вербицкий А. А. Контекстное обучение: формирование мотивации / А. А. Вербицкий // Высшее образование в России. - 1998. - № 1. - С. 101-107. 2. Воробйова Т. В. Щодо реалізації положень контекстного навчання у процесі фахової підготовки майбутніх медиків [Електронний ресурс] / Т. В. Воробйова. Режим доступу: http://archive.nbuv.gov.ua/portal/Soc_Gum/Pfto/2011_19/files/ P1911.pdf. 3. Дичківська I. М. Інноваційні педагогічні технології : [підручник] / I. М. Дичківська. - $\quad$ [2-ге $\quad$ вид., $\quad$ доп.]. - $\quad$ К. : Академвидав, 2012. - 349 с. 4. Наволокова Н. П. Енциклопедія педагогічних технологій та інновацій / Н. П. Новолокова. - Х. : Основа, 2009. - 176 с. 5. Пометун О. І. Сучасний урок. Інтерактивні технології навчання : [наук.-метод. посіб.] / О. І. Пометун, Л. В. Пироженко. - К. : А.С.К., 2004. - 192 с.

\section{ХМАРО ОРІСНТОВАНЕ НАВЧАЛЬНЕ СЕРЕДОВИЩЕ, ВІРТУАЛІЗАЦІЯ, МОБІЛЬНІСТЬ - ОСНОВНІ НАПРЯМКИ РОЗВИТКУ ЗАГАЛЬНОЇ СЕРЕДНЬОЇ ОСВІТИ ХХІ СТОЛІТТЯ}

Литвинова С.Г. Хмаро орієнтоване навчальне середовище, віртуалізація, мобільність - основні напрямки розвитку загальної середньої освіти ХХІ століття.

У статті на основі узагальнення наукових результатів і дослідження стану впровадження інформаційно-комунікаційних технологій у навчально-виховний процес уточнено напрямки стратегічного розвитку загальної середньої освіти у XXI столітті.

Ключові слова: хмаро орієнтоване навчальні середовище, віртуалізація, мобільність, середня освіта, 3К-технології. 
Литвинова С. Г. Облако ориентированная учебная среда, виртуализация, мобильность - основные направления развития общего среднего образования XXI века.

В статье на основании обобщения научных результатов и исследования состояния внедрения информационно-коммуникационных технологий в учебновоспитательный процесс автор уточняет направления стратегического развития общего среднего образования в XXI веке.

Ключевые слова: облако ориентированная учебная среда, виртуализация, мобильность, среднее образование, 3К-технологии.

Lytvynova S. Cloud computing, virtualization, mobility - the main directions of development of general secondary education of the XXI century.

The article by summarizing scientific results and research status of information and communication technologies in the educational process, the author clarifies the strategic development of secondary education in the XXI century.

Key words: cloud computing, virtualization, mobility, secondary education, 3Ktechnology.

За останні роки здійснено низку заходів щодо реформування середньої освіти, підвищення її якості, доступності та конкурентоспроможності.

Проте, повільне здійснення інформатизації системи освіти, недостатня відповідність освітніх послуг вимогам суспільства, впровадження у навчальновиховний процес інноваційних та інформаційно-комунікаційних технологій стримують розвиток середньої освіти в Україні [7].

Стратегія розвитку національної системи освіти, що має набути випереджального безперервного характеру, повинна формуватися адекватно сучасним інтеграційним процесам і формувати безпечне інноваційне навчальне середовище, підвищувати якість освіти на інноваційній основі, розвивати наукову діяльність i здійснювати безперервну інформатизацію освіти, інтегрувати національну систему освіти до європейського освітнього простору, що забезпечить стійкий рух та розвиток України в першій чверті XXI століття [7; 8].

Ураховуючи технологічну модернізацію суспільства та задля реформування системи освіти затверджено відповідні державні цільові програми, зокрема Державну цільову програму впровадження в навчально-виховний процес загальноосвітніх навчальних закладів інформаційно-комунікаційних технологій «Сто відсотків» на період до 2015 року, Державну цільову соціальну програму підвищення якості шкільної природничо-математичної освіти на період до 2015 року, Національну стратегію розвитку освіти в Україні на період до 2021 року [7].

Виконання Державних програм створило умови задля позитивних змін в освіті, що були узагальнені на Форумі міністрів освіти європейських країн «Школа XXI століття: Київські ініціативи». На Форумі було проголошено сім напрямів євроінтеграції дошкільної та середньої освіти, серед яких «ІКТ-освіта без кордонів», «Новій освіті Європи - новий європейський учитель», «Спільна історія без розділових ліній», «Від шкіл-партнерів до партнерів-країн», «Толерантність», «Через мову до взаєморозуміння». Тому нині на перший план виступають такі пріоритети, як удосконалення навчально-виховного процесу, впровадження сучасних інформаційно-комунікаційних технологій, доступність та ефективність освіти, підготовка учнів до життєдіяльності в інформаційному суспільстві [7; 8]. 
Незважаючи на стрімку інтеграцію ІКТ та широке впровадження новітніх засобів у навчально-виховний процес, протягом останніх років залишаються нерозв'язаними такі проблеми: стан оновлення парку комп'ютерної техніки залишається незадовільним; залишається обмеженим доступ учасників навчального процесу до електронних освітніх ресурсів; незадовільна якість і доступність Інтернет-послуг, відсутність регіонального освітнього провайдера; необхідність великої кількості паперових документів задля організації й підтримки навчальновиховного процесу; відсутність системного оновлення методик застосування засобів IКТ у навчальній діяльності; відсутність єдиних стандартів i регламентів функціонування системи електронного документообігу.

Розв'язання цих проблем можливе завдяки впровадженню хмаро орієнтованих навчальних середовищ, забезпечення мобільності учасників та віртуалізація організаційно-методичних компонентів навчально-виховного процесу.

Використання хмарних обчислень в освіті розкрито у працях В. Бикова, М. Жалдака, О. Спіріна, С. Семерікова, Ю. Триуса, М. Шишкіної, перспективи впровадження хмарних обчислень відображено у працях О. Гриб'юк, використання хмарних обчислень задля професійного розвитку вчителя (зарубіжний досвід) досліджували М. Шиненко, Н. Сороко, розвиток віртуальних предметних спільнот учителів-предметників, проектування віртуальних кабінетів, учительських відображено у працях С. Литвинової.

Водночас варто зазначити, що перспективи розвитку і впровадження хмаро орієнтованих навчальних середовищ у загальноосвітніх навчальних закладах науковцями досліджувалися недостатньо.

Метою статmі є дослідження стратегічного розвитку загальної середньої освіти в питаннях упровадження хмарних обчислень.

Уходження України до глобального інформаційного простору, розбудова суспільства вільного доступу до інформації та знань, надання електронних адміністративних послуг, реалізація пріоритетів і здійснення заходів Національної програми інформатизації, спрямованих на розвиток інформаційно-комунікаційних технологій та інформаційного суспільства спонукають педагогічну спільноту до неперервних змін в освіті.

Сучасні тенденції, що викликають необхідність змін в освіті, відображаються у змінах в комунікації, співпраці, навчанні; знання відтворюються не лише на паперових носіях, а в спільнотах, мережах, хмарних сховищах; багато видів неявної навчальної діяльності відбувається поза стінами класних кімнат, набирає обертів інфоосвіта.

Модернізація й комп'ютеризація середньої школи проводиться не просто сама собою, як певна данина новому оберту технічного прогресу, а спільними зусиллями керівників управлінь освітою, загальноосвітніх навчальних закладів, вчителів, науковців, програмістів, виробників електронних освітніх ресурсів. Така продуктивна взаємодія має зумовити створення нового інформаційного освітнього середовища, у якому визначальною стає інтеграція інформаційних та освітніх підходів до формування змісту освіти, добору методів і технологій навчання.

Стан розвитку освіти в Україні, як загалом, так і зокрема загальної середньої освіти, залишається складним. Цей стан має ознаки кризових явищ, з-поміж яких: недостатнє фінансування освітньої галузі; застаріла матеріально-технічна база, зростаюча кількість аварійних навчальних закладів; необгрунтоване скорочення мережі загальноосвітніх навчальних закладів; відсутність достатньої кількості навчальних програм, підручників, посібників і технічних засобів навчання; зневага 
до престижу професії вчителя; відсутність єдності у діях усіх гілок влади щодо розв'язання проблем освіти; недостатня участь громадськості, суспільства, батьків у процесах життя школи тощо [7; 8].

Президент Національної академії педагогічних наук України Василь Кремень наголосив, що «протягом останніх років у системі середньої освіти відбулася низка позитивних зрушень, що є результатом спільної діяльності Міністерства освіти і науки, органів управління освітою на місцях і всієї педагогічної громадськості, педагогічних колективів та їхніх керівників» [8].

На Міжнародному науковому конгресі «Інформаційне суспільство в Україні», що відбувся 29 жовтня 2013 року у м. Києві (http://congress.ogp.gov.ua) та в Концептуальних засадах розвитку електронної освіти в Україні було зроблено акцент на стратегічних напрямах розвитку суспільства нашої держави.

На сучасному етапі розвитку ми можемо стверджувати про три тренди хмарних обчислень: усі ми будемо у «хмарах», усі ми будемо мобільними, «хмари» на стику всього, зазначив Президент Hi-tech холдинга KM Core Уткін Є. (http://congress.ogp.gov.ua).

Директор 3 технологічної політики компанії «Майкрософт Україна» М. Шмельов доповнив, що нині стрімко розвиваються 10 найпопулярніших технологій: інтернет-речі (послуги), інтегровані пристрої й екосистеми (в одному і тому ж середовищі сумісні), гібридні IT i хостинг віртуальних пристроїв (аутсорсинг непрофільних підприємств), великі дані (неструктуровані дані, оброблення яких дає всеосяжні дані), кінцевий користувач має доступ до аналітики i може нею управляти, керування ризиками (кіберзлочинність, упровадження BOYD-технологій), корпоративні AppStore\&HTML5, персональні хмари і безшовні пристрої, соціальні нішеві обчислення, портативні технології і природні інтерфейси.

Завдяки тому, що Україна взяла курс на реалізацію свого потенціалу за рахунок інновацій, перед загальною середньою освітою постало питання спрямувати світові тенденції розвитку IT-сфери на формування нового навчальновиховного середовища задля підвищення якості надання освітніх послуг і розвитку конкурентоспроможного учня.

Упровадження різноманітних проектів 3 інформаційно-комунікаційних технологій у навчальний процес дало поштовх до підвищення рівня ІКТкомпетентності вчителів, розуміння стратегічних напрямків розвитку освіти та створили умови задля впровадження хмарних технологій, віртуалізації i найголовніше - мобільності учасників навчально-виховного процесу. Нова парадигма розвитку має відображення і в позитивному досвіді впровадження проектів з використання ІКТ у системі загальної середньої освіти.

Першість у використанні мережних технологій задля міжнародного спілкування i проектної діяльності треба віддати iEARN. Це безкоштовна, неприбуткова мережа, яка допомагає вчителям та учням використовувати Інтернет та різноманітні технології для співпраці задля покращання стану освіти. Це були перші кроки у використання інтернет-технологій.

Проект «Навчання для майбутнього» (iteach.com.ua) було спрямовано саме на вчителів, підвищення їх комп'ютерної компетентності та на учнів, зокрема, їх комп'ютерну грамотність під час роботи над проектами. Нині проект «Навчання для майбутнього» набув нового розвитку - здійснюється навчання вчителів щодо основ використання онлайн-інструментів. Саме використання технологій веб.2.0 спонукало до розвитку компетентностей співпраці над спільними документами. 
Щоденник.ua (shodennik.ua) - це безкоштовний електронний щоденник (для учня) i журнал (для навчального закладу). Цей сервіс доступний усім школам України. Для його використання достатньо зареєструвати навчальний заклад, навчити вчителів заносити дані про досягнення учнів, пропуски занять та домашні завдання в режимі онлайн. Портал підтримується розробниками, задля активізації діяльності на порталі проводяться конкурси, підтримується чат-спілкування тощо.

За підтримки компанією Майкрософт проекту «Партнерство в навчанні» (pilnetwork.com) почали формуватися віртуальні предметні спільноти [4]. Цей онлайнресурс підтримує режим навчання вчителів технологіям 3 обов'язковим тестуванням, розміщено відеофільм про використання Windows 8 для навчальних цілей. Посилено «електронну мотивацію» вчителів: педагогам та керівникам шкіл, які активно використовують ресурси мережі, надають спеціальні електронні значки. Значки можна отримати за проходження індивідуально визначеного шляху професійного розвитку, підтримку тематичних дискусій, додавання матеріалів, змістовних коментарів, покращення перекладу [5]. Використання мережі надало змогу розвинути компетентності з діяльності вчителя у предметних спільнотах.

Удалий проект «Віртуальний клас» (www.wiziq.com) було реалізовано педагогами Оболонського району м.Києва. Вони відпрацювали навички онлайн навчання учнів, які через тривалу хворобу не відвідували школу. Інтеграція до звичайного навчального середовища учня, який 3 певних причин не міг ходити до школи, надала змогу переглянути традиційні форми навчання [2]. Саме вони зробили перший крок до використання хмарних технологій.

Проект «Один учень - один комп'ютер» мав на меті створення новітнього навчального середовища школи, в якому кожен учень i вчитель може використовувати персональний нетбук під час навчального процесу. Навчальне середовище учня наповнилося новими інноваційними моделями застосування інформаційно-комунікаційних технологій, а саме учні молодших та середніх класів виконували завдання i працювати самостійно, брали участь у навчальних дослідницьких проектах. Локальна мережа, створена за допомогою Wi-Fi, надала змогу використати програмне забезпечення Classmate PC для створення умов особистісно орієнтованого навчання. Така колаборація вчителя та учнів - це відпрацювання навичок співпраці вчителя й учнів засобами IКТ.

Усі ці кроки (впровадження проектів) надали змогу набути компетентностей 3 використання віртуальних технологій навчання, спілкування, створення умов для спільної роботи над електронними документами, що створило умови для впровадження хмарних та віртуальних технологій у роботі з учнями. Як ми бачимо, педагоги беруть активну участь у кардинальних змінах системи освіти i спостерігають за поступовим упровадженням таких нових форм навчання, як онлайн.

Для розуміння стратегічних напрямів розвитку середньої загальної освіти, розглянемо детальніше основні поняття, які були окреслені вище.

За визначенням ЮНЕСКО хмарні обчислення - це метод зберігання даних i надання програмного забезпечення кінцевому користувачеві. Проте зазначено, що Веб 2.0 - це певний вид програмного забезпечення.

Під хмаро орієнтованим навчальним середовищем ми розуміємо спеціально створене середовище для організації навчально-виховного процесу з використанням різноманітного програмного забезпечення як послуги. Наприклад, office 365 , Googleсервісів тощо. 
Основні принципи побудови хмаро орієнтованого навчального середовища (ХOHC) $[2 ; 3 ; 4 ; 5 ; 6]$ : зорієнтованість на інтереси і потреби учасників навчальновиховного процесу, єдині технічні стандарти і взаємна сумісність, конфіденційність та інформаційна безпека, відкритість, відповідність міжнародним стандартам, добровільність, ієрархія, колективне використання даних, авторське право, миттєве реагування.

Можливості для учасників навчально-виховного процесу: корпоративна пошта, планування спільної роботи (створення календарів), співпраця над документами (Word, Excel, PowerPoint, OneNote), організація і проведення онлайнсемінарів, нарад, конференцій, миттєві повідомлення, підтримка сайту, аутсорсінг.

Принципи розбудови і можливості ХОНС відповідають Концептуальним засадам розвитку електронної освіти в Україні, що мають забезпечити [1; 6]: створення технологічної інфраструктури загальноосвітніх навчальних закладів, переважно орієнтованих на публічні, приватні хмарні та гібридні технології; розвиток нових видів цифрових ресурсів (електронних лекцій, цифрових підручників), викладацькі та навчальні ресурси - лекція і підручник - віднесено до навчальних ресурсів; створення інтерактивних засобів навчання; розвиток віртуальних спільнот викладачів і методистів задля обміну цифровими освітніми ресурсами; розвиток нових освітніх методик, інтегрованих 3 IКТ; визначення організаційної структури, відповідальної за впровадження системи електронного навчання в навчальних закладах.

Основними суб'єктами ХОНС стають: учні, вчителі, керівники шкіл, батьки тощо. Автоматично об'єднуються у предметні спільноти суб'єкти ХОНС, яким надається можливість користуватися корпоративною поштою, планувати спільну роботу методичних об'єднань, створювати спільні календарі заходів, співпрацювати над документами (Word, Excel, PowerPoint, OneNote), організовувати і проводити онлайн-семінари, тематичні наради, конференції, надсилати миттєві повідомлення, підтримувати сайт спільноти.

Віртуалізація навчального процесу - це використання, розробка програмними засобами і збереження будь-яких об'єктів у хмарних сховищах. Наприклад, документи, створені у хмаро орієнтованому середовищі, віртуальні класи, лабораторії, бібліотеки, карти тощо.

Система загальношкільного планування, яка містить перспективний план, план роботи школи на навчальний рік, календарний план на півріччя, графіки загальношкільних заходів, плани роботи учнівських організацій, розклади уроків і позаурочних занять, може бути легко перенесеною у хмаро орієнтоване середовище, у якому документи набирають ознак «віртуальних» [3].

Мобільність учасників навчально-виховного процесу - можливість учня або вчителя мати доступ до хмаро орієнтованого навчального середовища будь-де і будь-коли, і з будь-якого гаджета. Наприклад, доступ до навчальних матеріалів 3 планшета з OC Android чи ультрабуку з OC Windows 8.1.

Характерною особливістю мобільного навчання $\epsilon$ постійна комунікація 3 вчителем, іншими учнями, науковцями, експертами. Обмін даними відбувається за допомогою безпровідного або провідного зв'язку, який одночасно може надати можливість збагачення доступу до навчальних матеріалів, спостережень, досліджень або додаткових розвивальних програм.

Окрім технологій, які розвиваються, питання використання сучасних гаджетів у загальноосвітніх навчальних закладах виходить на перший план. 
Наявність в учнів різноманітних комп'ютерів (телешетів, планшетів, ноутбуків, нетбуків, смартфонів) створює умови для його мобільності - за умови надання різноманітних онлайн-сервісів провайдерами i їх підтримки цими пристроями. Використання BOYD-технологій (bring your own device) надало б змогу розв'язати низку технологічних проблем в системі загальної середньої освіти, а саме на кожному уроці можна продемонструвати відеофрагмент, організувати роботу у групах, парах, створити умови для роботи з віртуальною лабораторією i провести онлайн-конференцію з однолітками.

Шкільна BOYD-технологія (bring your own device at school aбо BOYD- S) це використання власних гаджетів у навчально-виховному процесі середньої школи.

Така технологія в майбутньому не вимагатиме від учителя акцентувати увагу на пристроях, їх наявності чи відсутності, а надає змогу зосередити увагу на технології проведення уроку. Водночас виникатиме потреба у стандартизації такого обладнання для використання у школі. Тобто розроблення вимог до розмірів екрана, забезпечення можливості підзарядки тощо.

Однак нині це створює більшою мірою проблеми, аніж рішення. Для одночасного використання різноманітних гаджетів у навчальному процесі вчителі не мають ні певних навичок технологічної організації уроку, ні критеріїв оцінювання роботи учнів.

Упровадження хмаро орієнтованого навчального середовища в систему загальної середньої освіти є організаційно й методично виваженим рішенням, яке вкладається в основні тенденції розвитку інформаційно-комунікаційних технологій у найближчі роки. Використання такого середовища не вимагає від учасників навчально-виховного процесу використання конкретних гаджетів або специфічного програмного забезпечення, воно створює умови для мобільності як учня, так і вчителя.

Зважаючи на тенденції, що склалися з розвитком інформаційно-комунікаційних технологій, актуальними можна вважати три основні напрями взаємодії: комунікацію, колаборацію та кооперацію, як «Три К-технологія» взаємодії [3; 6].

До переваг використання хмаро орієнтованого навчального середовища можна віднести: підвищується активізація навчальної діяльності учнів та мотивація до навчання; спостерігається економія навчального часу - акцент переміщується на відпрацювання навичок, розвиток логічного мислення, пам'яті; $\epsilon$ можливість взаємодії з освітніми сервісами, що загалом підвищують ефективність навчального процесу.

Спрямування діяльності навчальних закладів до віртуалізації, використання хмарних технологій і створення умов задля формування мобільного учня та вчителя надає підстави стверджувати, що учасники навчально-виховного процесу отримають вільний доступ до різноманітних даних незалежно від матеріального становища, національності, місця проживання і стану здоров'я.

Отже, ключовим завданням освіти у XXI столітті $\epsilon$ розвиток новітніх інформаційно-комунікаційних технологій, спрямованих на створення умов мобільності навчання, нових форм проведення уроків, взаємодії, організації навчального-виховного процесу, орієнтованих на майбутне.

Подальшого дослідження потребує зарубіжний та український досвід учителів щодо використання хмаро орієнтованих середовищ у навчально-виховному процесі загальноосвітніх навчальних закладів.

\section{Література}

1. Концептуальні засади розвитку електронної освіти в Україні [Електронний pecypc]. - Режим доступу: http://www.mon.gov.ua - Назва 3 екрану. 
2. Литвинова C. On-line навчальне середовище вчителя-предметника загальноосвітнього навчального закладу [Електронний ресурс]. - Режим доступу: http: //journal.iitta.gov.ua/ index.php/itlt/ article/ view/356/313UnJjrHC8DR4 3. Литвинова С. Віртуальна учительська за хмарними технологіями / Литвинова С. Г. // Комп'ютер у школі та сім’ї. - 2013. - № 2 (106) - С. 23-25. 4. Литвинова С. Віртуальні предметні спільноти / С. Г. Литвинова // Інформаційно-комунікаційні технології в освіті: досвід, інновації, технічне забезпечення : збірник матеріалів Всеукраїнської науково-практичної конференції (1-2 березня 2012 року м. Суми). - Суми : РВВ СОІППО, 2012. - С. 39-42. 5. Литвинова С. Хмарні технології: особливості діяльності вчителів-предметників у віртуальних предметних спільнотах / C. Г. Литвинова // Теорія та методика електронного навчання. Вип. IV. - Кривий Ріг : Видавничий відділ КМI, 2013. - С. 165-170. 6. Литвинова С. Хмаро орієнтоване середовище управління школою/ С. Г. Литвинова // Міжнародний науковий конгрес «Інформаційне суспільство в Україні». Тези доповідей. - Київ : Український Дім, 2013. - С. 64-66. 7. Національна стратегія розвитку освіти в Україні на період до 2021 року [Електронний ресурс]. - Режим доступу: http://www.president.gov.ua/ru/ documents/15828.html. 8. Парламентські слухання «Доступність та якість загальної середньої освіти : стан і шляхи поліпшення» [Електронний ресурс]. - Режим доступу: http://www.mon.gov.ua .

УДК 37:316.77

Ірина Онищенко

\section{СУТНІСТЬ І СТРУКТУРА ІНФОРМАЦІЙНО-КОМУНІКАЦІЙНОГО ПЕДАГОГІЧНОГО СЕРЕДОВИЩА}

Онищенко I. B. Сутність i структура інформаційно-комунікаційного педагогічного середовища.

У статті розкрито сутність інформаційно-комунікаційного педагогічного середовища, визначено його роль у професійній підготовці майбутніх педагогів. Обгрунтовано думку про те, що інформаційно-комунікаційне педагогічне середовище $\epsilon$ складною педагогічною системою, яка охоплює інформаційні, організаційні, інтелектуальні, методичні, технічні, програмні ресурси й підвищує ефективність та якість підготовки фахівців.

Ключові слова: інформатизація освіти, інформаційне середовище, інформаційно-комунікаційне педагогічне середовище, інформаційно-комунікаційні технології, професійна підготовка.

Онищенко И. В. Сущность и структура информационно-коммуникационной педагогической среды.

В статье раскрыта сущность информационно-коммуникационной педагогической среды, определена ее роль в профессиональной подготовке будущих педагогов. Обосновано мнение о том, что информационнокоммуникационная педагогическая среда является сложной педагогической системой, которая включает информационные, организационные, интеллектуальные, методические, технические, программные ресурсы и повышает эффективность и качество подготовки специалистов. 